Archaeological Journal

\title{
Remarks on Wolsey's College and the Priory of St. Peter and St. Paul, Ipswich
}

\section{Nina Frances Layard}

To cite this article: Nina Frances Layard (1899) Remarks on Wolsey's College and the Priory of St. Peter and St. Paul, Ipswich, Archaeological Journal, 56:1, 211-215, DOI: 10.1080/00665983.1899.10852820

To link to this article: http://dx.doi.org/10.1080/00665983.1899.10852820

里 Published online: 16 Jul 2014.

Submit your article to this journal $₫$

Џ Article views: 2

Q View related articles 5 
REMIARKS ON WOLSEY'S COLLEGE AND THE PRIORY OF ST. PETER AND ST. PAUL, IPSWICH.

BY NINA FRATCES LAYARD.

Wolsey's College, erected upon the site of the Priory of St. Peter and St. Paul, consisted either of additions to the buildings already standing, or was a completely new edifice, the exact position of which it is difficult to determine. As to the time of its commencement historians have naturally accepted the date recorded on the foundation stone which was discovered in a wall in Woulfern's Lane more than a hundred years ago. On it was the following inscription :- "In the year of Christ, 1528, and the twentieth of Henry VIII, King of England, and on the 15th of June, laid by John, Bishop of Lincoln." This, however, does not seem to tally with a letter written by the Cardinal to the Count de Beaumont dated " 26 th day of January in the year 1528." In it he says, "Some time since I began to build and erect two Colleges to the honor of God Our Creator, one in Ipswich which is the place of my birth," etc., unless we are to suppose that the less important parts of the establishment were already commenced before the foundation stone was duly laid.

Wolsey had obtained bulls from the Pope and letters patent from King Henry VIII, for the suppression of the Priory in order to make room for the college, and for its endowment he had also procured possession of many other small monasteries, including Snape, Dodnash, Wikes, Hoakesley, Tiptree, Rumburgh, Felixstow, Bromehill, Blithburgh and Mountjoy. It was the Cardinal's intention that the college should be built of stone from Harwich Cliff, but he had been misinformed as to the quantity obtainable, and when he forwarded a request to the Dowager Countess of Oxford to allow him to take " as much stone from her cliff at Farwich as should be needful for his purpose," he was met by a somewhat. spirited refusal from that lady, who protested that " no stone existed at Harwich at least in the cliff" except that which 
formed a foreland which could not be removed without endangering the town.

Such a reply hardly suited the high-handed Wolsey, who was quite unaccustomed to being thwarted in his desires, and his uncourteous rejoinder that "her refusal to his request arose from another and unworthy motive," throws a side-light upon the arrogant character of the King's favourite.

It was useless, however, to resist a request which was practically a command, but we can read both disgust and irritation in the final reply of the Countess, "Be it hurtful or otherwise, your Grace to do your pleasure."

And so what stone could be obtained was brought from Harwich, but the supply soon fell short and Wolsey was obliged "to apply to the French King for permission to take stone from the quarries at Caen."

This scarcity of stone in the neighbourhood may account for the fact of the gateway, which is still standing, being built of brick,

If we can place any reliance upon the small plan of the college given in a quaint little work by Mr. Grove, of Richmond, dated 1761, and entitled "Two Dialogues in the Elysian Fields between Cardinal Wolsey and Cardinal Ximenes," it would appear that the actual entrance to the college building stood considerably behind the present gateway, and this would in all probability have been built of the stone obtained from Harwich and Caen, but Clark, in his History of Ipswich, gives it as his opinion that "the front of the College was fronting to the West," and founds his belief on the fact that "the old church was taken down for the purpose of enlarging the site of the new buildings."

Wolsey's Gate, as it is called, which is now standing, must have been merely an entrance gate to the grounds of the college. It is constantly mentioned as the only portion of Wolsey's buildings left standing, but I have recently made a careful examination of the site, with the result that a large part of the original wall, which was. built at the same time as the gateway, is found to be still existing:

Starting from the left of the gateway, it takes a turn to the right and is continued along St. Peter's churchyard, 
till at the back of the chancel of the church it meets and is fitted on to an old rubble wall which has every appearance of having belonged to the ancient Priory of St. Peter and St. Paul, although Wooderspoon informs us that "but few remains of the Priory have been found, and none above ground." This rubble wall continues for a distance of $43 \frac{1}{2}$ feet, when Wolsey's brick wall is again built on to the older structure, and continues as far as the boundary of the Turnery yard. Here, turning again to the right, it becomes the dividing wall between Mr. Edward Turner's property and Mr. Oxborrow's on the left, and Turret Lane on the right.

It is not difficult to trace the wall, as the particular coping which may be seen very clearly on the left of the gateway is continued throughout. In it the bricks are so arranged that the corner of each brick projects exactly in the centre (see Illustration No. 1). This is not the case with the coping on the rubble wall, although apparently an attempt has been made to copy it, but here the bricks are placed at a slightly different angle, from which I presume that the rubble wall, though made use of by Wolsey, was of previous date.

The discovery of a built-up Tudor archway at the far end of the brick wall, where it turns to the right, and exactly opposite to Wolsey's Gate, confirms my conclusion that the whole of the wall is connected with the old entrance. (See Mllustration No. 2.)

This arch, which is 5 feet wide, is at the present time about 4 feet above ground, but Mr. Edward Turner informs me that the ground is higher here by 4 or 5 feet than it was originally. This would give a height of 8 or 9 feet to the archway. In order to show the correspondence between the two arches, I have had two photographs taken, one of the inner side of Wolsey's Gate, where the shape of the archway is very clearly shown (see Illustration No. 3), and the other of the arch in the wall, which has nearly disappeared after the accumulation of years. (See Illustration No. 2.)

In tracing out the probable position occupied by the college the discovery of this arch is of considerable value. It carries the property certainly as far as and into that now occupied by Mr. Oxborrow, and I think the founda- 
tions of a rubble wall may be traced up Turret Lane below the more recent brick wall, especially at the entrance to a small garden gate opening into the lane.

Whether the site occupied by the old Priory and subsequently by the college extended as far as Rose Lane must at present remain an open question, though I gather that the extent of the college property, mentioned in 'Taylor's Index Monasticus as being six acres, was the measurement of the estate of the Priory, which is all, as far as I know, that was granted to the Cardinal.

In comparing various records a curious question arises as to the demolishing of St. Peter's church. In Taylor we have not only an account of its suppression, but it is mentioned that "since therefore the inhabitants of St. Peter's had no place for their attendance on divine service the Cardinal determines to place them under the pastoral care of the clergy presiding over those churches which are nearest to the Monastery of St. Peter, and accordingly he appoints the above William Capon to go to the aforesaid college where the Church of St. Peter formerly stood, and to assemble the parishioners in a convenient place in order to consider the matter, \&c." At the same time, we find among the expenses incurred by the Cardinal at this time the following items in connection with the maintenance of the church :-

"Item one to kepe the vestry and the churche in due order and cleainesse taking by the yere $\mathrm{xl}^{\mathrm{s}}$.

"Item oon to be bellringer taking by the yere $\mathrm{xxvj}^{\mathrm{s}}$ viij".

"Item for the com'ons of viij queresters after vja a weke ev'y of them $\mathbf{x}^{1}$ viijs.

It was also arranged that the annual procession to the chapel of our Lady of Grace in Lady Lane should start "from his College and the Church of St. Peter."

The question naturally arises as to whether Wolsey after destroying the church which was situated on the site chosen by him for his college, rebuilt it in its present position, but considering that from the time of the commencement of the college to its dissolution in 1530 less than three years had elapsed, this seems hardly probable. Noreover the north side of the present church and indeed the whole of the existing structure bears marks of greater antiquity than would thus be allowed for, and even if we 
PRIORT OF ST. PETER AND ST. PAUI, IPSWICII. 215

suppose that Wolsey moved it farther south, leaving the present north wall standing, we must then satisfy ourselves that the outside of the present north wall was originally the inside of the old south wall, after which the difficulty of want of time for the rebuilding must be overcome.

The following ballad of the period taken from Bacons Annals shows that there existed an undercurrent of revolt against the methods adopted by the Cardinal to raise funds for his Colleges.

"Hym men do worshyppe w" prayers and lyghte

The peopyll do curse bothe day and nighte;

Thys ys the Comon voyse.

$W^{\text {th }}$ Abbayes good thy colage $\mathrm{g}^{\mathrm{u}}$ byldeste, $W^{\text {th }}$ pore mens good thy place $\mathrm{y}^{\mathbf{u}}$ gldeste;

How Canste $y^{u}$ thys Reioyse?" 